\title{
Elsykkel til jobb gir treningseffekt
}

\section{Bruk av elsykkel gir like god tre- ningseffekt som gange i motbakke og kan anbefales for å få folk i økt fysisk aktivitet.}

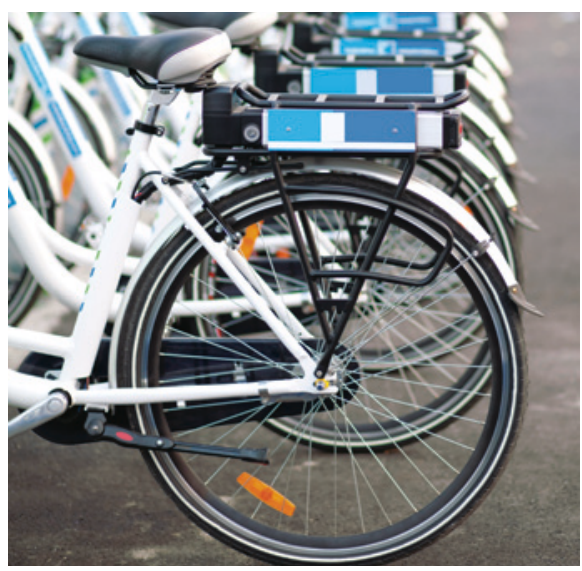

Illustrasjonsfoto Istockphoto
Bruk av sykkel ved reise til og fra jobb og skole er en mulighet for å inkludere fysisk aktivitet i moderne dagligliv. En elsykkel er en sykkel med påmontert elektrisk motor som hjelper til slik at man ikke behøver å bruke like mye krefter som på en vanlig sykkel. Sveitsiske forskere har undersøkt om bruk av elsykkel gir tilstrekkelig arbeidsintensitet til å gi positive helseeffekter (1).

18 friske, mye stillesittende forsøkspersoner i alderen 26-46 år gjennomførte en typisk jobbreise i Lausanne på fire forskjellige måter: Gange i nesten $2 \mathrm{~km}$ i bratt motbakke, vanlig sykkel i vel $5 \mathrm{~km}$ i svak motbakke, elsykkel med moderat assistanse i vel $5 \mathrm{~km}$ i svak motbakke og elsykkel med maksimal assistanse i vel $5 \mathrm{~km}$ i svak motbakke. Fart, tid, hjertefrekvens, oksygenopptak, opplevd intensitet og opplevd behov for dusjing i etterkant ble registrert. De fire reisemåtene ga en arbeidsintensitet av maksimal hjerterytme på henholdsvis $72 \%$, $85 \%, 75 \%$ og $80 \%$.
Forfatterne konkluderer med at elsykkel kan gjøre det mulig for folk flest å overvinne topografiske og logistiske hindringer ved sykkelpendling. Det gir dermed mulighet til å inkludere fysisk aktivitet i hverdagen uten å sette av ekstra tid. Elsykkel kan konkurrere med bil på reisetid i urbane områder, og den fysiske motstanden kan tilpasses syklistens fysiske form og motivasjon. Økt bruk av elsykkel som transportmiddel kan få store positive effekter for folkehelse, miljø og kø.

\section{Stian Ellingsen Lobben \\ stianlobben@gmail.com \\ Nytorget legesenter}

Litteratur

1. Gojanovic B, Welker J, Iglesias K et al. Electric bicycles as a new active transportation modality to promote health. Med Sci Sports Exerc 2011: 43: $2204-10$

\section{Lave D-vitaminnivåer gir ikke mer luftveisinfeksjon}

\section{Det er ingen sammenheng mellom vitamin D-nivå og forekomst av selvrapportert luftveisinfeksjon blant voksne personer i Troms $\varnothing$.}

Flere studier har antydet at det er en sammenheng mellom vitamin D og infeksjoner. Vi har nylig publisert en studie fra Tromsø der 6350 eldre og middelaldrende personer fikk målt nivået av vitamin $\mathrm{D}$ (serum 25 hydroksyvitamin D), samtidig som de svarte på spørsmål om de hadde hatt symptomer på luftveisinfeksjon siste uke (1). Hos deltakere med selvrapportert luftveisinfeksjon ble tilleggsfaktorer som røyking, selvrapporterte sykdommer, soleksponering, inntak av fiskemat eller vitaminer, kroppsmasseindeks (BMI) og spirometri kartlagt. Måling av CRP ble tatt med $\mathrm{i}$ analysene for å øke validiteten ved spørsmål om luftveisinfeksjon.

$791(13 \%)$ deltakere rapporterte symptomer på luftveisinfeksjon siste uke. Vitamin D-nivå ble klassifisert i kvartiler der man tok høyde for deltakermåned og røyking. Forekomsten av symptomer økte ikke med lavere vitamin D-nivå. Det var ingen sammenheng mellom varighet av symptomer og vitamin D-nivå. Frekvensen av symptomer og samtidig CRP-nivå $\geq 5 \mathrm{mg} / 1$ viste samme fordeling i vitamin D-kvartiler som symptomer alene.

$\mathrm{Vi}$ fant ingen signifikant sammenheng mellom symptomer på luftveisinfeksjon og inntak av fisk, omega-3-tilskudd, vitaminog/eller andre kostholdstilskudd eller soleksponering. Hos dem som brukte tran eller fiskeoljekapsler daglig eller av og til, var det en lavere forekomst av symptomer på luftveisinfeksjon siste uke $(p=0,04)$. Dersom inntak av tran beskytter mot luftveisinfeksjon, skyldes det trolig noe annet enn vitamin D.

\section{Steinar Robertsen}

sro@sbls.no

Universitetet i Troms $\varnothing$ - Norges arktiske universitet

\section{Litteratur}

1. Robertsen S, Grimnes G, Melbye H. Association between serum 25 -hydroxyvitamin $D$ concentration and symptoms of respiratory tract infection in a Norwegian population: the Troms $ø$ Study. Public Health Nutr 2013; e-publisert 9.5.2013.

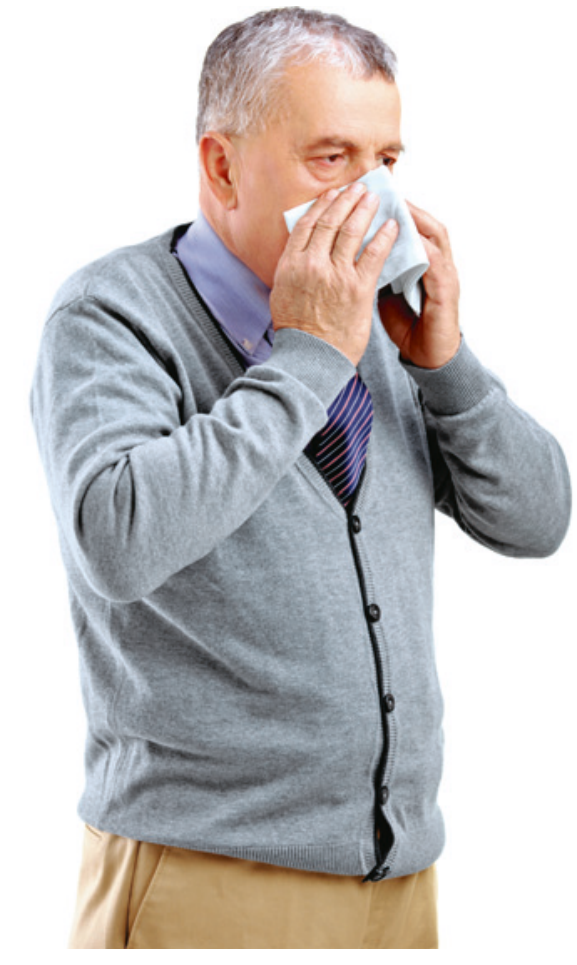

Illustrasjonsfoto Istockphoto 